\title{
Pengaruh Kemampuan Manajemen Konflik, Kontrol Stres Kerja dan Self-Efficacy Pada Kinerja Guru
}

\author{
Sabriana Oktaviani Gintulangi ${ }^{1}$, I Kadek Satria Arsana ${ }^{2}$ \\ ${ }^{1}$ Fakultas Administrasi dan Ilmu Sosial, Universitas Bina Taruna Gorontalo \\ Email : sabrianna05@gmail.com \\ ${ }^{2}$ Fakultas Administrasi dan Ilmu Sosial, Universitas Bina Taruna Gorontalo \\ *Corresponding Email: satriaarsana28@gmail.com
}

\begin{abstract}
The implementation of this study aims to 1) To know the positive direct influence of conflict management ability on teacher work achievement in SMPN as Pinolosian, 2) To know the positive direct influence of work stress control on teacher work achievement, 3) To know the direct positive influence of self-efficacy on teacher's work performance, 4) To know the positive direct influence of conflict management ability on teacher self-efficacy, 5) To know the positive direct influence of stress control on teacher self-efficacy. This research method uses a quantitative approach, with data collection techniques are questionnaires and documentation. As well as data analysis using descriptive and inferential. The results of this study showed that 1) there is a positive direct influence of Conflict Management Ability on teacher work performance 2) there is a positive direct influence of work stress control on teacher work performance 3) there is a positive direct influence of self-efficacy on teacher work performance, 4) there is a positive direct influence of conflict management ability on teacher self-efficacy, 5) there is a positive direct influence of stress control on teacher self-efficacy.
\end{abstract}

Keywords : Ability to Manage Conflict; Work Stress Control; Self Efficacy; Work Achievement

\begin{abstract}
Abstrak
Pelaksanaan penelitian ini bertujuan kepada 1) Untuk mengetahui pengaruh langsung positif dari Kemampuan Manajemen Konflik terhadap prestasi kerja guru di SMPN sekecamatan pinolosian, 2) Untuk mengetahui pengaruh langsung positif dari pengendalian stres kerja terhadap prestasi kerja guru, 3) Untuk mengetahui pengaruh positif langsung dari self efficacy terhadap kinerja kerja guru, 4) Untuk mengetahui pengaruh langsung positif dari kemampuan manajemen konflik pada self efficacy guru, 5) Untuk mengetahui pengaruh langsung positif dari kontrol stres pada self efficacy guru. Metode penelitian ini menggunakan pendekatan kuantitatif, dengan teknik pengumpulan data adalah kuesioner, dan dokumentasi. Serta analisis data menggunakan deskriptif dan inferensial. Hasil penelitian ini menunjukkan bahwa 1) ada pengaruh langsung positif dari kemampuan manajemen konflik pada kinerja kerja guru 2) ada pengaruh langsung positif dari pengendalian stres kerja pada kinerja kerja guru 3) ada pengaruh langsung positif dari self efficacy pada kinerja kerja guru, 4) ada pengaruh langsung positif dari kemampuan manajemen konflik pada self efficacy guru , 5) ada pengaruh langsung positif dari kontrol stres pada self efficacy guru.
\end{abstract}

Kata Kunci : Kemampuan Mengelola Konflik; Kontrol Stres Kerja; Self Efficacy; Pencapaian Kerja 


\section{PENDAHULUAN}

Prestasi kerja yang dimiliki seorang guru akan memberikan hal yang positif terhadap perkembangan instansi/ sekolah. Sehingga pemimpin mengadakan beberapa penilaian untuk menilai setiap guru yang memiliki prestasi kerja yang efektif. Karena tingkat keberhasilan dari suatu instansi akan dilihat dari berapa efektifnya prestasi yang dimiliki oleh guru. Faktor prestasi kerja yang perlu dinilai adalah kuantitas kerja, kualitas kerja, keandalan, inisiatif, kerajinan, sikap, dan kehadiran. Menurut Byar dan Rute dalam (Sutrisno, 2009) mengemukakan adanya dua faktor yang mempengaruhi prestasi kerja, yaitu faktor individu dan faktor lingkungan. Faktor-faktor Individu yang dimaksud adalah : 1). Usaha (effort), yang menunjukkan sejumlah sinergi fisik dan mental yang digunakan dalam menyelenggarakan gerkan tugas. 2). Abilities, yaitu sifat personal yang diperlukan untuk melaksanakan suatu tugas. 3) Role /Tak Perception, yaitu segala perilaku dan aktivitas yang dirasa perlu oleh individu untuk menyelesaikan suatu pekerjaan. Sedangkan faktor-faktor lingkungan yang mempengaruhi prestasi kerja adalah : 1). Kondisi fisik 2). Peralatan 3). Waktu 4). Material 5). Pendidikan 6). Supervisi 7). Desain organisasi 8). Pelatihan.

Konflik yang timbul pada guru maka akan mengakibatkan rendanya peluang dalam mencapai prestasi kerja. Karena pada dasarnya tingkat konflik yang tinggi akan menimbulkan Stres, hal ini tidak lepas dari kegiatan-kegiatan yang dilakukan seorang individu atau kelompok. Tingginya konflik berpengaruh pada kinerja seorang guru pada saat pengambilan keputusan dan dapat merugikan salah satu pihak. Guru-guru yang ada di sekolah menengah pertama negeri sekecamatan pinolosian sering mendapati konflik antar guru dalam memberikan pendapatnya, hal ini terlihat ketika pendapat salah satu guru tidak diterima dengan baik maka akan berujung pada konflik, tidak jarang pula konflik terjadi karena saling ketergantungan dalam pekerjaan.

Stres yang ditimbulkan bisa mempengaruhi kinerja seorang guru dan berdampak pada guru lain dan siswa. Pashkow, F.J dan Libov dalam (Wahyudi \& Akdon, 2005) Stres adalah perasaan tertekan dan penuh kecemasan yang dialami seseorang karena sulit mencapai kebutuhan dan keinginannya. Seperti halnya konflik, Stres juga jangan hanya dilihat dari sisi negatifnya. Namun Stres juga bisa memiliki sisi positifnya. Guru yang memiliki self afficacy yang tinggi cenderung memiliki prestasi dan produktifitas kerja yang baik, karena dia akan berusaha menyelesaikan pekerjaan yang sedang dia kerjakan walaupun sedang berada dalam tekanan akan tetapi cenderung mengalami konflik dan hal ini akan menghalangi guru dalam mencapai kinerja dan prestasi yang efektif. Kebanyak yang mempengaruhi produktifitas kerja seorang guru adalah psikologinya.

\section{METODE PENELITIAN}

Penelitian ini dilaksankan pada Sekolah Menengah Pertama yang ada di Kecamatan Pinolosian, dengan subyek penelitiannya adalah guru. Penelitian ini menggunakan metode deskriptif kuantitatif dengan jenis penelitian Path Analysis atau analisis jalur, (Sarwono, 2011), (Caraka \& Sugiarto, 2017). Sample pada penelitian ini sebanyak 95 orang. Teknik pengumpulan data dalam penelitian ini adalah dengan menggunakan angket. Teknik analisis data yang digunakan adalah analisis deskriptif dan inferensial. Teknik analisis deskriptif digunakan untuk memperoleh gambaran karakteristik penyebaran nilai setiap skor variabel yang diteliti. Deskripsi data skor hasil penelitian didasarkan pada nilai rata-rata (mean), median dan modus data berkelompok. Selain itu juga dihitung 
varians data. Sebaran data berdasarkan tabel distribusi frekuensi data berkelompok divisualisasikan dalam bentuk histogram. Sedangkan analisis inferensial dilakukan melalui uji statistik.

\section{HASIL DAN PEMBAHASAN}

Secara jelas data penelitian dipaparkan dalam empat kelompok data skor, terdiri dari: (a) prestasi kerja (Y), (b) kemampuan Mengelola konflik (X1), (c) pengendalian Stres (X2), dan (d) self afficacy guru (X3). Data ini dideskripsikan dengan maksud untuk memberikan gambaran umum mengenai penyebaran atau distribusi data semua variabel tersebut. Distribusi data berupa ukuran gejala sentral, ukuran distribusi, maupun penyajian data. Data-data yang disajikan setelah mengalami pengolahan data dengan menggunakan teknik statistik deskriptif, diantaranya: skor tertinggi, skor terendah, nilai rata-rata, simpangan baku, modus, dan median. Selain datadata tersebut, disajikan dalam bentuk tabel distribusi frekuensi dan histogram. Secara umum hasil perhitungan disajikan dalam Tabel di bawah ini.

Tabel 1. Descriptive Statistical Techniques

\begin{tabular}{lllll}
\hline \multirow{2}{*}{ Statistik Dasar } & \multicolumn{4}{c}{ Variabel } \\
& $\mathrm{X}_{1}$ & $\mathrm{X}_{2}$ & $\mathrm{X}_{3}$ & $\mathrm{Y}$ \\
\hline Skor maksimum & 95 & 80 & 60 & 100 \\
Skor minimum & 62 & 42 & 39 & 61 \\
Rata-Rata & 83,98 & 68,87 & 49,79 & 84,88 \\
Standar deviasi & 6,72 & 7 & 4,77 & 8,28 \\
Median & 84 & 69,12 & 49,92 & 85,37 \\
Modus & 83,64 & 68,8 & 46,17 & 84,07 \\
\hline
\end{tabular}

Sumber: analisis data 2019

\section{A. Pengujian Hipotesis}

Sebelum melakukan pengujian hipotesis, pengujian model dilakukan berdasarkan persamaan struktural yang telah dibangun. Persamaan struktural yang dimaksud adalah sebagai berikut:

$Y=\rho_{\mathrm{y} .1} X_{1}+\rho_{\mathrm{y} .2} X_{2}+\rho_{\mathrm{y} .3} X_{3}+\varepsilon$

$X_{3}=\rho_{3.1} X_{1}+\rho_{3.2} X_{2}+\varepsilon$

\section{Pengujian Hipotesis dan Persamaan Struktural Jalur Model Satu}

Pada tabel 2 menunjukan bahwa koefisien jalur dapat dilihat pada kolom beta menghasilkan skor sebesar 0,414 yang dibulatkan menjadi 0,41 untuk pengaruh kemampuan mengelola konflik terhadap prestasi kerja guru, 0,249 yang dibulatkan menjadi 0,25 untuk pengaruh pengendalian Stres terhadap prestasi kerja guru, 0,552 yang dibulatkan menjadi 0,55 untuk pengaruh self afficacy terhadap prestasi kerja guru. Seluruh koefisien jalur signifikan karena digambarkan koefisien $t_{\text {hitung }}$ lebih besar

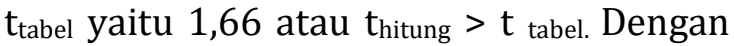
demikian estimate value $\mathrm{Y}=0,41 \mathrm{X}_{1}+$ $0,25 \mathrm{X}_{2}+0,55 \mathrm{X}_{3}$

Tabel 2: Coefficients

\begin{tabular}{|c|c|c|c|c|c|}
\hline \multicolumn{6}{|c|}{ Coefficients $^{\mathbf{a}}$} \\
\hline \multirow[b]{2}{*}{ Model } & \multicolumn{2}{|c|}{$\begin{array}{l}\text { Unstandardized } \\
\text { Coefficients }\end{array}$} & \multirow{2}{*}{$\begin{array}{c}\begin{array}{c}\text { Standardized } \\
\text { Coefficients }\end{array} \\
\text { Beta } \\
\end{array}$} & \multirow[b]{2}{*}{$\mathrm{t}$} & \multirow[b]{2}{*}{ Sig. } \\
\hline & B & Std. Error & & & \\
\hline (Constant) & 33.110 & 11.252 & & 2.943 & .004 \\
\hline Kemampuan Mengelola Konflik & .315 & .072 & .414 & 4.383 & .000 \\
\hline Pengendalian Stres & .286 & .131 & .249 & 2.186 & .031 \\
\hline Self Afficacy & .822 & .129 & .552 & 6.387 & .000 \\
\hline
\end{tabular}


Hipotesis 1 : Terdapat pengaruh langsung positif kemampuan mengelola konflik terhadap prestasi kerja guru.

Hipotesis statistic :

$\mathrm{H}_{0}: \rho_{y .1}=0$
$\mathrm{H}_{\mathrm{a}}: \rho_{y .1}>0$

Hasil pengolahan SPSS 25 pada Tabel coefisien 2 struktur 1 , diperoleh koefisien jalur pengaruh langsung kemampuan mengelola konflik terhadap prestasi kerja guru sebesar $\rho_{\text {y.1 }}=0,41$; $t_{\text {hitung }}=4,38$; pada taraf nyata $\alpha=0,05 t_{\text {tabel }}$ $=1,66$ sehingga $t_{\text {hitung }}>t_{\text {tabel. }}$. Dengan demikian $\mathrm{H}_{0}$ ditolak dan $\mathrm{H}_{\mathrm{a}}$ diterima, yaitu terdapat pengaruh langsung positif kemampuan mengelola konflik terhadap prestasi kerja guru.

Hipotesis 2 : Terdapat pengaruh langsung positif pengendalian stres terhadap prestasi kerja guru. Hipotesis statistic dalam penelitian ini adalah sebagai berikut.

Hipotesis statistic:

$\mathrm{H}_{0}: \rho_{y .2}=0$

$\mathrm{H}_{\mathrm{a}}: \rho_{y .2}>0$

Berdasarkan hasil pengolahan SPSS 25 pada Tabel coefisien, diperoleh koefisien jalur pengaruh langsung pengendalian stres terhadap prestasi kerja guru sebesar $\rho_{\mathrm{y} .2}=0,25$; thitung $=$ 2,18; pada taraf nyata $\alpha=0,05, t_{\text {tabel }}=1,66$ sehingga $t_{\text {hitung }}>t_{\text {tabel. }}$. Dengan demikian $\mathrm{H}_{a}$ diterima dan $\mathrm{H}_{0}$ ditolak, yaitu terdapat pengaruh langsung positif pengendalian stres terhadap prestasi kerja guru.
Hipotesis 3 : Terdapat pengaruh langsung positif self afficacy terhadap prestasi kerja guru. Hipotesis statistic dalam penelitian ini adalah sebagai berikut.

Hipotesis statistic :

$\mathrm{H}_{0}: \rho_{y .3}=0$

$\mathrm{H}_{\mathrm{a}}: \rho_{y .3}>0$

Hasil pengolahan SPSS 25 pada Tabel 4.17, diperoleh koefisien jalur pengaruh langsung self afficacy terhadap prestasi kerja guru sebesar $\rho_{\mathrm{y} .3}=0,55$; $t_{\text {hitung }}=6,38$; pada taraf nyata $\alpha=0,05 t_{\text {tabel }}$ $=1,66$ sehingga $t_{\text {hitung }}>t_{\text {tabel. }}$. Dengan demikian $\mathrm{H}_{\mathrm{a}}$ diterima dan $\mathrm{H}_{0}$ ditolak, yaitu terdapat pengaruh langsung positif self afficacy terhadap prestasi kerja guru.

Kerangka hubungan kausal empiris antara X1, X2, dan X3 terhadap Y dapat dibuat melalui persamaan struktural Model-1 berikut. $Y=\rho_{\mathrm{y} .1} \mathrm{X}_{1}+\rho_{\mathrm{y} .2} \mathrm{X}_{2}+\rho_{\mathrm{y} .3} \mathrm{X}_{3}$ $+\varepsilon$ atau $Y=0,41 X_{1}+0,25 X_{2}+0,55 X_{3}$

\section{Pengujian Hipotesis dan Persamaan Struktural Jalur Model dua}

Koefisien jalur sebagaimana dapat dilihat pada kolom beta menghasilkan skor 0,240 dan dibulatkan menjadi 0,24 untuk pengaruh kemampuan mengelola konflik terhadap self afficacy, dan 0,462 dibulatkan menjadi 0,46 untuk pengaruh pengendalian Stres terhadap self afficacy. Seluruh koefisien jalur tersebut signifikan karena pada koefisien $t$ lebih besar dari $t_{\text {tabel }}$ atau $t_{\text {hitung }}>t_{\text {tabel. }}$. Dengan demikian estimate value $\mathrm{X}_{3}=0,24 \mathrm{X}_{1}+0,46 \mathrm{X}_{2}$

Tabel 3 : Coefficients

\begin{tabular}{|l|c|c|c|c|c|}
\hline \multicolumn{2}{|c|}{ Coefficients $^{\mathbf{a}}$} \\
\hline \multirow{2}{*}{ Model } & \multicolumn{2}{|c|}{$\begin{array}{c}\text { Unstandardized } \\
\text { Coefficients }\end{array}$} & $\begin{array}{c}\text { Standardized } \\
\text { Coefficients }\end{array}$ & & \\
\cline { 2 - 6 } & $\mathrm{B}$ & Std. Error & Beta & $\mathrm{t}$ & Sig. \\
\hline & 13.264 & 5.746 & & 2.308 & .023 \\
\hline $\begin{array}{l}\text { (Constant) } \\
\text { kemampuan mengelola } \\
\text { konflik }\end{array}$ & .183 & .069 & .240 & 2.662 & .009 \\
\hline pengendalian stres & .310 & .061 & .462 & 5.113 & .000 \\
\hline
\end{tabular}


Hipotesis 4 : Terdapat pengaruh langsung positif kemampuan mengelola konflik terhadap self afficacy

Hipotesis statistic

$\mathrm{H}_{0}: \rho_{X 3 X 1}=0$

$\mathrm{H}_{\mathrm{a}}: \rho_{X 3 X 1}>0$

Berdasarkan hasil pengolahan SPSS 25 pada Tabel 3 struktur 2, diperoleh koefisien jalur pengaruh langsung kemampuan mengelola konflik terhadap self afficacy sebesar $\rho_{3.1}=0,24 ; t_{\text {hitung }}=$ 2,66 ; pada taraf nyata $\alpha=0,05, t_{\text {tabel }}=$ 1,66 , sehingga $t_{\text {hitung }}>t_{\text {tabel. }}$ Dengan demikian $\mathrm{H}_{0}$ ditolak dan $\mathrm{H}_{\mathrm{a}}$ diterima, artinya terdapat pengaruh langsung positif kemampuan mengelola konflik terhadap self afficacy.

Hipotesis 5 : Terdapat pengaruh langsung positif pengendalian Stres kerja terhadap self afficacy

Hipotesis statistic

$\mathrm{H}_{0}: \rho_{X 3 X 2}=0$

$\mathrm{H}_{\mathrm{a}}: \rho_{X 3 X 2}>0$

Berdasarkan hasil pengolahan SPSS 25 pada Tabel 4.17 struktur 2, diperoleh koefisien jalur pengaruh langsung strategi pengendalian Stres kerja terhadap self afficacy sebesar $\rho_{3.2}=0,46$; $t_{\text {hitung }}=5,11$; pada taraf nyata $\alpha=0,05, t_{\text {tabel }}=1,66$, sehingga $t_{\text {hitung }}>t_{\text {tabel }}$. Dengan demikian Ho ditolak dan Ha diterima, artinya terdapat pengaruh langsung positif pengendalian Stres kerja terhadap self afficacy.

Kerangka hubungan kausal emperis antara X1 dan X2 terhadap X3 dapat dibuat melalui persamaan struktural Model-2 berikut. $X_{3}=\rho_{3.1} X_{1}+\rho_{3.2} X_{2}+\varepsilon$ atau $\mathrm{X}_{3}=0,24 \mathrm{X}_{1}+0,46 \mathrm{X}_{2}$.

\section{HASIL DAN PEMBAHASAN}

Hasil pengujian menemukan bahwa kemampuan mengelola konflik berpengaruh langsung positif terhadap prestasi kerja yang ditunjukan oleh nilai koefisien jalurnya yang signifikan yakni $\mathrm{p}_{\mathrm{y} .1}=0,41 ; \mathrm{t}_{\text {hitung }}=4.38 ; \mathrm{t}_{\text {tabel }}=1,66$, ternyata harga $t$ hitung labih besar dari $t$ tabel atau $t_{\text {hitung }}>t_{\text {tabel }}$. Dengan demikian maka hipotesis yang diajukan peneliti bahwa terdapat pengaruh langsung positif kemampuan mengelola konflik terhadap prestasi kerja dapat diterima.

Konflik yang kurang di kelolah dengan baik maka akan berdampak negative dan menurunnya prestasi kerja.. Bahwa pengelolan konflik yang dilakukan oleh setiap guru melali beberapa cara, 1) menghindari hal-hal yang dapat memunculkan konflik, 2) mengerjakan pekerjaan yang dapan menyenangkan hati, 3) menjalin komunikasi yang baik dengan kapala sekolah maupun staf stake holder. Jika hal tersebut tidak dapat dilakukan maka guru berusaha mencari alternative lain untuk menyelesaikan konflik tersebut. Penelitin ini memiliki pendapat yang sama dengan (Lasulika, 2019) bahwa terdapat pengaruh langsung positif dan signifikan pengendalian konflik terhadap kinerja guru. Jika pengelolaan konflik dilakukan dengan baik maka akan menghasilkan prestasi kerja yang baik. Namun jika seorang guru tidak memiliki kemampuan dalam mengelola konflik maka akan terjadi panurunan dalam mencapai prestasi kerja. konflik yang sering timbul ada adalah konflik antar pribadi, hal ini dikemukan oleh Campnell, R. F. et. al. dalam (Wahyudi, 2015) konflik antar individu disekolah melibarkan siswa, guru, kepala sekolah dan orang tua.

Hasil pengujian menemukan bahwa pengendalian stres berpengaruh langsung positif terhadap prestasi kerja yang ditunjukan oleh nilai koefisien jalurnya yang signifikan yakni sebesar $p_{y .2}=0,25$; $t_{\text {hitung }}=2,18$; pada taraf nyata $\alpha=0,05$, $t_{\text {tabel }}=1,66$, sehingga $t_{\text {hitung }}>t_{\text {tabel }}$. Dengan demikian hipotesis yang diajukan peneliti bahwa terdapat pengaruh langsung positif pengendalian stres terhadap prestasi kerja guru diterima.

Temuan ini memberikan informasi bahwa prestasi kerja dapat ditentukan oleh pengendalian Stres. Penelitian terdahulu yang dilakukan oleh (Nur, 
2013) stres kerja berpengaruh terhadap kinerja pegawai. Artinya semakin tinggi stres yang dirasakan seseorang maka akan memberikan dampak negative terhadap kinerja guru.

Hal ini sejalan dengan (Robbins, 2003) tingkat Stres yang mampu dikendalikan mampu membuat guru melakukan pekerjaan yang lebih baik, karena akan membuat mereka meningkatkan intensitas kerja, kewaspadaan dan kemampuan berekreasi. Namun tingkat Stres yang tinggi akan membuat kinerja mereka mengalami penurunan. Beberapa guru cenderung melakukan hal-hal yang dapat menghilangkan Stres seperti melakukan senam dan membagi cerita dengan teman sesama guru, sehingga akan meningkatkan prestasi kerja. Pada penelitian terdahulu (Ismail et al., 2009) menyatakan bahwa studi terbaru dalam bidang Stres menunjukan guru yang memiliki kemampuan untuk mengelola Stres mempunyai pengaruh yang signifikan pada kinerja karyawan. Artinya jika guru dapat mengendalikan Stres dengan baik dan benar maka meningkat pula prestasi kerja yang dimiliki.

Hasil pengujian menemukan bahwa self afficacy berpengaruh langsung positif terhadap prestasi kerja yang ditunjukan oleh nilai koefisien jalurnya yang signifikan yakni sebesar $\rho_{\mathrm{y} .3}=0,55$; thitung $=6,38$; pada taraf nyata $\alpha=0,05, \mathrm{t}_{\text {tabel }}=$ 1,66 , sehingga $t_{\text {hitung }}>t_{\text {tabel. }}$ Dengan demikian hipotesis yang diajukan peneliti terdapat pengaruh langsung positif self afficacy terhadap prestasi kerja guru diterima.

Penelitian ini memberikan informasi bahwa prestasi kerja dapat ditentukan oleh self afficacy. Yang merupakan keyakinan pada diri seseorang dalam menimbulkan kekuatan untuk mengerjakan pekerjaan ketika sedang berada pada keadaan tertekan. Self afficacy memberikan dampak yang positif bagi sesorang dalam menyelesaikan setiap pekerjaan. self afficacy sendiri merupaka variable penting bagi guru. Hal ini dikarenakan setiap pekerjaan difokuskan pada keyakinan seseorang untu menyelesaikan pekerjaan dalam pencapai tujuan. Menurut (Schunk \& Mullen, 2012) variable Self afficacy berpengaruh positif terhadap prestasi matematika. Sejalan dengan penelitian terdahulu oleh Hanun (2013) bahwa terdapat pengaruh langsung positif efikasi diri terhadap kinerja kepala sekolah. Sama halnya dengan prestasi kerja, bahwa kepala sekolah juga harus memiliki self affikasi untuk meningkatkan kinerja secara baik.

Hasil pengujian menemukan bahawa kemampuan mengelola konflik berpengaruh langsung positif terhadap self afficacy sebesar $\rho_{3.1}=0,24 ; t_{\text {hitung }}=$ 2,66 ; pada taraf nyata $\alpha=0,05, t_{\text {tabel }}=$ 1,66 , sehingga $t_{\text {hitung }}>t_{\text {tabel }}$. Hal tersebut menyatakan bahwa hipotesis yang diajukan diterima. Melihat hal tersebut bahwa konflik pada dasarnya adalah perbedaan ciri-ciri yang dibawah oleh individu dalam satu interaksi dengan situasi yang wajar terjadi dan tidak dapat dihindari. Sebagian guru memiliki konflik oleh sebab itu guru harus memiliki self afficacy yang tinggi dalam menyelesaikan konflik tersebut. Kemampuan mengelola konflik terhadap self efficacy telah teruji kebenarnya, artinya semakin baik pengelolaan konflik maka secara bersamaan akan semakin tinggi pula self afficacy yang dimiliki seorang guru.

Hasil pengujian pada hipotesis mengemukakan bahwa pengaruh pengendalian Stres kerja terhadap self afficacy sebesar $\rho_{3.2}=0,46$; $t_{\text {hitung }}=5,11$; pada taraf nyata $\alpha=0,05, t_{\text {tabel }}=1,66$, sehingga $t_{\text {hitung }}>t_{\text {tabel }}$. Dengan demikian hipotesis diterima. Jika Stres dapat dikendalikan dengan baik oleh seorang guru maka tingkat efikasi diri juga akan meningkat sehingga akan menghasilak pekerjaan yang diinginkan. Namun sebaliknya jika seseorang tidak mampu mengendalikan Stres maka efikasi diri akan menurun, hal tersebut akan 
berdampak langsung pada penyelesaian pekerjaan.

Efikasi diri dalam pengendalian Stres itu dipengaruhi oleh ketidaksesuaian dengan tuntutan kerja. Setiap pegawai perlu ditingkatkan dalam menjaga kelangsungan dan menjamin adanya ketenangan dalam menyelesaikan pekerjaan. Pengendalian Stres kerja dan efikasi diri merupakan hal yang saling berkaitan. Sehingga jika Stres dikendalikan dengan baik dengan otomatis keyakinan diri juga akan meningkat.

\section{KESIMPULAN}

Terdapat pengaruh langsung positif dan signifikan kemampuan mengelola konflik terhadap prestasi kerja guru Hal ini berarti semakin tinggi kemampuan mengelola konflik maka akan semakin maningkat prestasi kerja. Terdapat pengaruh langsung positif dan signifikan pengendalian stres terhadap prestasi kerja. Semakin baik pengendalian stres maka akan semakin meningkat prestasi kerja. Terdapat pengaruh langsung positif dan signifikan self afficacy terhadap prestasi kerja. Artinya jika efikasi diri meningkat maka restasi kerja akan meningkat. Terdapat pengaruh langsung positif dan signifikan kemampuan mengelola konflik terhadap self afficacy.Terdapat pengaruh langsung positif dan signifikan pengendalian stres terhadap self afficacy.

\section{DAFTAR PUSTAKA}

Caraka, R. E., \& Sugiarto, S. (2017). Path analysis terhadap faktor-faktor yang mempengaruhi prestasi siswa. Jurnal Akuntabilitas Manajemen Pendidikan, 5(2),

212-219. https://doi.org/10.21831/amp.v5i2. 10910

Ismail, A., Yao, A., \& Yunus, N. K. Y. (2009). Relationship Between Occupational Stress and Job Satisfaction: An Empirical Study in Malaysia.
Romanian Economic Journal, 12(34). http://www.rejournal.eu/sites/rejou rnal.versatech.ro/files/articole/2009 -04-01/2134/ismailazmanetall.pdf

Lasulika, F. (2019). Pengaruh Pengendalian Konflik, Budaya Sekolah, Dan Motivasi Kerja Terhadap Kinerja Guru SD Di kecamatan Suwawa. Thesis, 1(750715020).

https://publikasi.pascasarjana.ung.ac .id/public/storage/ta/2019/11/21/ ARTIKEL_FIRDA_LASULIKA.pdf

Nur, S. (2013). Konflik, stres kerja dan kepuasan kerja pengaruhnya terhadap kinerja pegawai pada Universitas Khairun Ternate. Jurnal EMBA: Jurnal Riset Ekonomi, Manajemen, Bisnis Dan Akuntansi, 1(3).

https://doi.org/10.35794/emba.v1i3 .2238

Robbins, S. . (2003). Perilaku Organisasi, Konsep dan Aplikasi. Gramedia.

Sarwono, J. (2011). Mengenal path analysis: sejarah, pengertian dan aplikasi. Ilmiah Manajemen Bisnis. https://media.neliti.com/media/pub lications/98454-ID-mengenal-pathanalysis-sejarah-pengertia.pdf

Schunk, D. H., \& Mullen, C. A. (2012). Selfefficacy as an engaged learner. In Handbook of research on student engagement (pp. 219-235). Springer. https://doi.org/10.1007/978-14614-2018-7_10

Sutrisno, E. (2009). Manajemen Sumber Daya Manusia. Kencana Prenada Media Group.

Wahyudi, \& Akdon. (2005). Manajemen Konflik Dalam Organisasi. Alfabeta.

Wahyudi, D. (2015). Manajemen Konflik Dan Stres Dalam Organisasi. Alfabeta. 